\title{
o insulto da feiura na escola: insurreições contra o capital
}

\author{
steferson zanoni roseiro ${ }^{1}$ \\ universidade federal do espírito santo, brasil \\ orcid id: http:/ / orcid.org/0000-0003-1424-2281 \\ janete magalhães carvalho ${ }^{2}$ \\ universidade federal do espírito santo, brasil \\ orcid id: http:/ / orcid.org/0000-0001-9906-2911
}

\section{resumo}

Perguntando-se o que aconteceria com as lógicas de controle se a feiarada tomasse conta da escola, esse artigo toma a fabulação como um método de pesquisa para produzir fábulas de insurreição contra o Capital. Parte-se do princípio de que no contexto contemporâneo as práticas de embelezamento têm se constituído como um modo de controle sobre o corpo. Assim, a feiura - comumente reconhecido como oposto da beleza - é apresentado como um modo de enfrentamento à beleza reguladora. Metodologicamente, a pesquisa foi realizada em uma escola pública do município de Cariacica/ES. As fabulações foram realizadas em encontros com turmas de $6^{\circ}$ e $7^{\circ}$ anos com o intuito de produzir histórias de feiura como um modo de criar vida na escola, enfrentando as lógicas controladorascapitalísticas. No limite, mesmo o mais controlador dos corpos flerta livremente com a feiura sem temê-la. Antes de causar-lhe dor ou desespero, a feiura provoca um gosto inesperado pela vida. Por isso, justamente, a feiura recusa a ideia da paz mundial. A paz é fabricada para anestesiar os afetos, para que não haja conversação entre diferentes formas de vida. No lugar, a feiura atrai outras feiuras, ou, de modo ainda mais peculiar, produz feiura onde antes aparentava haver só belezas. E as feiuras fazem insurreições infinitamente.

palavras-chave: feiura; insurreição; resistência; fabulação; beleza.

\section{the insult of ugliness at school: insurrections against the capital}

\begin{abstract}
Wondering what would happen with the logics of control if the ugly took over the school, this article considers fabulation as a method of research to produce fables of insurrection against the Capital. It assumes that in the contemporary context, the embellishment practices have become a manner of control over the body. Thus, the ugliness commonly recognized as being the opposite of beauty - is presented as a way of confronting the regulator beauty. Methodologically, the research was conducted in a public school in the city of Cariacica/ES. The fabulations were created on encounters with classes of $6^{\text {th }}$ and $7^{\text {th }}$ grades with the objective of creating stories of ugliness as a manner of creating life in school, confronting the controlling-capitalistic logics. At the end, even the more controlling of bodies induces an unexpected taste for life. Precisely for that, ugliness refuses the idea of world peace. Peace is created to anesthetize affection, so there is no conversion between different forms of life. On the other hand, ugliness attracts ugliness, or, in an even more peculiar way, creates ugliness where before there seemed to be only beauty. And the ugliness creates insurrections infinitely.

keywords: ugliness; insurrection; resistance; fabulation; beauty.
\end{abstract}

\footnotetext{
${ }^{1}$ E-mail: zanoniroseiro@hotmail.com

2 E-mail: janetemc@terra.com.br
} 
o insulto da feiura na escola: insurreições contra o capital

\section{el insulto de la fealdad en la escuela: insurrecciones contra el capital}

\section{resumen}

Preguntándose qué pasaría con la lógica de control si la fealdad tomara el control en la escuela, este ensayo utiliza la fabulación como método de investigación para producir fábulas de insurrección contra el capitalismo. Se parte del principio de que en el contexto contemporáneo las prácticas embellecedoras se han constituido como una forma de controlar el cuerpo. De esta manera, la fealdade - generalmente reconocida como lo opuesto a la belleza - se presenta como una forma de confrontar la belleza del regulador. Metodológicamente, la investigación se realizó en una escuela pública en la ciudad de Cariacica / ES. Las fabulaciones se realizaron con estudiantes de sexto y séptimo grado con el objetivo de producir historias de fealdad como una forma de crear vida en la escuela, enfrentando la lógica de control capitalista. En el borde, incluso el cuerpo más controlador coquetea libremente con la fealdad sin ningún temor. En lugar de doler o entrar en pánico, la fealdad provoca un gusto inesperado por la vida. Por eso la fealdad rechaza la idea de la paz mundial. La paz se fabrica para anestesiar las afecciones, por lo que no hay conversación entre las diferentes formas de vida. En su lugar, la fealdad atrae más fealdad o, más peculiarmente, produce fealdad donde antes solo había bellezas. Y la fealdad insurrecta hasta el infinito.

palabras clave: fealdad; insurrección; resistencia; fabulación; belleza. 
o insulto da feiura na escola: insurreições contra o capital

\section{escola de gente feia}

Aristeves, Feioso, Josélia, Saci e outros tantos corpos-personagens nos invadem todas as vezes que entramos numa escola. Pessoas reais que encontramos em escolas, pessoas inventadas por outros que fazem ondulações na memória coletiva, pessoas recontadas que parecemos até conhecermos de tão próximas ficamos de suas histórias. Em suma, pessoas marcantes, reais, ainda que fabricadas; pessoas que fazem estardalhaço por corredores, salas de aula, quadras, coordenação. Todas as vezes que colocamos nossos pés dentro de uma escola, acabamos por sorrir diante daquilo que um tanto de professoras e professores chamam de desobediência. Obviamente, enquanto tais professores, é difícil sorrir diante de algumas desobediências. Não nos enganemos: ser desobedecido é complicado, ativa uma série de reações apaixonadas pelo poder. E elas não gostam de ser contrariadas.

Ainda assim, diante desse momento em que as políticas governamentais para a educação evocam a militarização das escolas como modelo a ser seguido, certos estudos sobre a desobediência fazem-se necessários. Estudos que afirmem sua potência. A desobediência, por vezes, é apenas essa força que irrompe ali onde traçamos uma linha muito bem delineada. Não quer dizer que seja sempre algo ruim, mas também não é necessariamente bom. Não é uma questão também de criar um tom romântico para as desobediências.

Talvez seja essa a causa de nossa paixão tão curiosa por escolas. É impossível a qualquer corpo cruzar os portões de entrada de uma escola e não topar, em menos de dez minutos, com assaltos de corpos devotos à desobediência. Numa escola, desobedece-se a todo o tempo. Às vezes, é-nos até possível pensar a escola como um grande laboratório de desobediência onde se experimenta quais são cabíveis e quais não. Quiçá, professoras e professores seriam quem avalia os abalos sísmicos dessas desobediências testadas nas escolas. Algumas passam, outras não.

Assim, portanto, somos convidados a pensar a escola. 
o insulto da feiura na escola: insurreições contra o capital

Corpos insurrectos nos mostram, com primazia, algo que por vezes esquecemos: o menino que nunca abriu um caderno na sala não é o que menos presta atenção nas aulas; a menina que se maquia três vezes em sala pode muito bem ser excelente em química e matemática; o gordo que nunca faz educação física não precisa ser sedentário; a menina que não sabe ler não tem nada de burra. Podemos não gostar das atitudes deles e do risco que eles representam em meio aos outros alunos, mas precisamos admitir ser apenas isso. Temos medo de reconhecer que nem todos precisamos saber de tudo e todas as coisas e que é demasiadamente enfadonho que todos saibamos das mesmas coisas ${ }^{3}$.

Por apresentarem um risco demasiado grande para a lógica do individualismo, esses corpos precisam ser desqualificados, precisam ser mal vistos pelos corpos em maior sintonia com os fluxos da maquinaria capitalística.

Assim, portanto, o capital, receoso desses corpos demasiado vívidos, gera códigos infinitos para capturar a vida. Os últimos cursos e obras de Foucault se preocuparam em falar do corpo governável; todavia, é a produção do corpo controlado de Deleuze (2013) que mais nos interessa. A questão não é exatamente a de como os corpos são governados, mas de perceber como códigos - pré-verbais, afetivos, linguísticos, semióticos etc. - se inscrevem sobre os corpos e permitem fazer agrupamentos, dissociações, apagamentos, trocas e quaisquer outras operações corpóreas possíveis.

O ponto jaz justamente nos modos de controle e funcionamento do Capital. Se o capitalismo se alimenta de nossos corpos, é preciso que enxerguemos os fluxos econômicos, as moedas, as cobranças e nossos desejos de consumo como fluxos que funcionam como regra da vida contemporânea.

3 É preciso indagar algo pouco discutido no campo dos currículos e das propostas de homogeneização curricular, isto é, precisamos indagar qual a lógica que rege o imperativo de um currículo comum a tudo e a todos. Desde o momento da retomada das discussões sobre a Base Nacional Comum Curricular, discutiu-se muito sobre a negação de diferenças (culturais, sociais, econômicas, políticas etc.); entretanto, quase não se fala que essa proposta de currículo homogeneizado só é possível graças à forte bandeira do individualismo. Em termos práticos, a partir do momento em que os corpos sabem exatamente as mesmas coisas, um corpo é totalmente descartável para o outro. Sabendo exatamente as mesmas coisas, seria desnecessária a partilha de saberes, ou, no mínimo, impensável. Aqui, os corpos serviriam apenas para contribuir para afazeres já estabelecidos para atividades em grupos. 
Se se fala de corpo ao falar do controle Capital, não podemos, de modo algum, ignorar as regras estéticas que lançadas sobre nós (LIPOVETSKY; SERROY, 2015; SANT'ANNA, 2014). Se o corpo é um dos alvos prioritários do exercício regulador da maquinaria capitalística, uma série de manuais, imagens e desejos corpóreos são lançados como fluxos a-significantes (LAZZARATO, 2014). Abrimos uma página qualquer de internet e encontramos fotografias de pessoas sorridentes, bem resolvidas, trabalhadoras que em nada devem a modelos e às antigas top model.

Conforme Caio Milito (2012) sugeria, fomos todos enquadrados pela lógica da estetização do corpo. Diante de tantos comerciais estéticos, aprendemos que beleza produz felicidade e um modo correto de agir e de estar no mundo. Ser belo implica um estar belo que tudo tem a ver com os modos como as pessoas agem.

Quando os corpos rompem padrões de comportamento, de imediato, dançam também por entre atitudes estéticas. A beleza - produção capitalística sobre o corpo - implica uma ética do bom comportamento. Aristeves - de nome próprio Feioso - irrompe a aula de Josélia e automaticamente a paz é rompida.

O corpo belo capitalisticamente produzido não é apenas o da loira magra e jovem. Há muito o Capital aprendeu a dividir seu outdoor entre loiras magras, morenas gordas, ruivas trans, mulheres tatuadas e quaisquer outras variações de corpos.

Não, a beleza alia-se a quem vive conforme um conjunto de regras mais ou menos propícias para o ideal capitalístico, em termos tanto de fluxos monetários quanto de continuidade de seus ideais. Na era dos anúncios de internet, não mais é preciso comprar e usar para garantir os lucros das empresas. Agora, bastam cliques em seus banners espalhados pelos sites, para que mais e mais pessoas vejam aquilo. Se um YouTuber ganha 1 real a cada 1000 acessos e YouTubers famosos no Brasil ganham, no mínimo, 400 mil ao ano ${ }^{4}$, dá para imaginar o poder de um clique para as empresas.

Se Denise Bernuzzi de Sant'Anna (2014) dizia que ser feio era uma questão de preferência ao analisar a história da beleza no Brasil ao longo do século XX,

\footnotetext{
${ }^{4}$ A título de curiosidade, o YouTuber com maior número de acessos no Brasil, Felipe Neto, tem uma renda anual que varia de 1 a 18 milhões de reais.
} 
o insulto da feiura na escola: insurreições contra o capital

hoje, onde a beleza é facilmente codificada via pequenos cliques e vídeos-tutoriais espalhados pelo YouTube, ser feio é quase uma doença, ou, antes, uma insurreição.

Por isso, justamente, colocamo-nos a traçar feiuras de escola, feiuras que produzem, nas escolas, lutas contra o Capital.

A fabulação como uma metodologia de pesquisa intervenção, foi realizada em uma escola pública do Município de Cariacica/ES. Ao todo, foram realizados 17 encontros com alunos de $6^{\circ}$ e $7^{\circ}$ ano do Ensino Fundamental com o intuito de produzir, em cada turma, cenas de escola que rompessem com o conceito padrão de beleza, feiura e com a imagem típica da escola como lugar de controle. Seis turmas foram envolvidas na produção, ficando cada turma responsável pela criação de um personagem e uma das fábulas produzidas. Os personagens iam se enredando às histórias de outras turmas, criando vínculos com questões imanentes à realidade vivificada pela comunidade escolar e questionando certas lógicas imperativas de escolas. Ao nos colocarmos em produção fabuladora, criávamos, de imediato, personagens que viviam a escola de um modo com o qual a enxergávamos e, ao mesmo tempo, gostaríamos que pudesse ser vivida.

Metodologicamente, partimos do pressuposto de que a fabulação criadora nada tem a ver com uma lembrança mesmo amplificada, visto que ao fabularem e inventarem, os corpos criam relações que não cabem em lógicas demasiado organizativas. Nessas relações criadas a partir de nossas capacidades de invenção e mundos - isto é, a fabulação -, podemos ensejar modos de existência pouco afoitos ao imediatismo da vida e, com isso, ampliar nossas percepções de futuro e de luta. Buscávamos justamente acessar e provocar os modos de percepção e o modo como nos afetamos pelas coisas que nos circulam. Diante, por exemplo, da professora autoritária, quais histórias que destacam a potência de vida são possíveis? O famoso bagunceiro pode algo diante dessas forças autoritárias? Mas somente os bagunceiros produzem insurreições? Os certinhos nada podem em termos de mudanças afetivas? E se olharmos bem para as figuras autoritárias, enxergaremos outras coisas? Outras vidas? Como nos sugerem Deleuze e Guattari (1992), fabular faz de nós corpos abertos às passagens afetivas.

É um vidente, alguém que se torna [um vidente]. Como contaria ele o que lhe aconteceu, ou o que imagina, já que é uma sombra? 
Ele viu na vida algo muito grande, demasiado intolerável também, e a luta da vida com o que a ameaça, de modo que o pedaço de natureza que ele percebe, ou os bairros da cidade, e seus personagens, acedem a uma visão que compõe, através deles, perceptos desta vida, deste momento, fazendo estourar as percepções vividas numa espécie de cubismo, de simultanismo, de luz crua ou de crepúsculo, de púrpura ou de azul, que não têm mais outro objeto nem sujeito senão eles mesmos criações, afetos, tristezas, alegrias, devires (DELEUZE; GUATTARI, 1992, p. 222).

Por isso, justamente, fabulamos. Criamos e, ao fazê-lo, damo-nos à produção de uma vida criável apenas no coletivo. Cumpre frisar que a fabulação, enquanto método, é usualmente usada de modo individual, onde o pesquisador/escritor, após o período de pesquisa, efetua uma escrita mais próxima à literatura. Aqui, ao contrário, partimos da fabulação enquanto uma produção coletiva, onde os próprios encontros com os participantes da pesquisa ocorreram em práticas de fabulação, isto é, de escrita literária coletiva, lembrando, evidentemente, dos princípios da fabulação enquanto resistência, enquanto invenção de um povo menor (DELEUZE; GUATTARI, 2014).

Assim, são apresentadas ao longo do texto duas das fábulas produzidas e são discutidas e dialogadas com o conceito de insurreição e de resistência. Conforme aprendemos com as crianças envolvidas na pesquisa, perguntávamos: se a feiarada toda fizesse algazarra na escola, o que restaria do controle capitalístico?

\section{fábula1: inimigo público $n^{\circ} 1$}

- Todo mundo, sentando.

Os alunos correram para sentar nos seus lugares. Josélia nunca foi flor que se cheire. Ela já dava aula naquela escola havia uns 25 anos e, como todo mundo que estudava lá morava ali a vida inteira, a maioria dos familiares dos alunos teve aula com ela. Curiosamente, ela era uma das únicas professoras em que nenhum dos alunos ousava colocar apelido ou falar com muita gracinha.

- Corrigi as provas de vocês e, como sempre, estou estupefata com tamanha ignorância - disse ela, começando a distribuir as provas uma por uma. - Está em ordem de nota, da menor para a maior. E não, não se preocupem, ninguém tirou uma nota boa de verdade. 
o insulto da feiura na escola: insurreições contra o capital

Imediatamente alguns sorrisos esperançosos murcharam.

- Estou acostumada com os garranchos de vocês e até mesmo com algumas imbecilidades que são ditas como respostas nas provas, mas, por obséquio, não quando eu dou uma cruzadinha para tentar facilitar a vida de vocês, não insistam em achar que eu coloquei o número errado de espaços na cruzadinha. Se eu coloco nove quadrados para "Sistema responsável por transformar o alimento em energia", eu não quero dizer dez quadrados. Se eu coloco nove, é porque bastam NOVE letras para escrever "digestivo". O que anula a "degustação" em massa daquele cantinho lá de trás que não cola, né?

Apenas uma menina na sala precisou disfarçar a risada em uma tosse "alérgica".

- Pois bem, como eu ia dizendo antes da Suzany me interromper com sua... tosse...

- JOSÉLIA, MINHA QUERIDA! SENTIU MINHA FALTA?

Todos se viraram para olhar a porta escancarada.

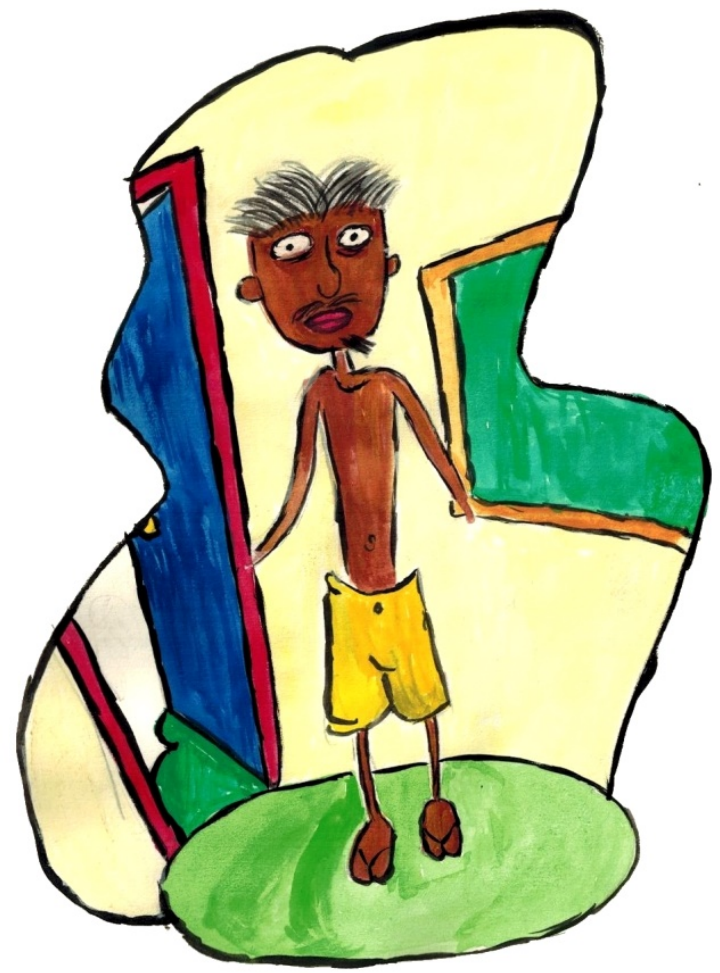

Imagem 1: De repente, Aristeves (aquarela). 
- Caraca, Saci, por que tu não me lembrou que era Josélia agora? Eu teria chegado mais cedo, mano...

Josélia, de repente, estava levemente avermelhada.

- Seu lugar, Aristeves.

- Já falei que não precisa dessas formalidades, Josélia. 'Cê me chama de Feioso que até faço o agrado de aprender mais vezes na sala só para ver essa sua cara bonitinha...

Mas mesmo Aristeves não tinha tanta coragem de manter Josélia irritada por tempo o suficiente. A velha nunca tinha encostado a mão em ninguém, mas alguns poucos que já tinham visto ela verdadeiramente irritada - e Feioso era um desses - sabiam que ela parecia quase a figura de um cão raivoso. Aristeves podia ser chamado de Feioso, mas, puta merda, ela irritada era grotesca.

- 'Fessora linda do meu coração, cadê minha prova?

- Não tem como eu entregar uma prova que nunca foi feita, Aristeves.

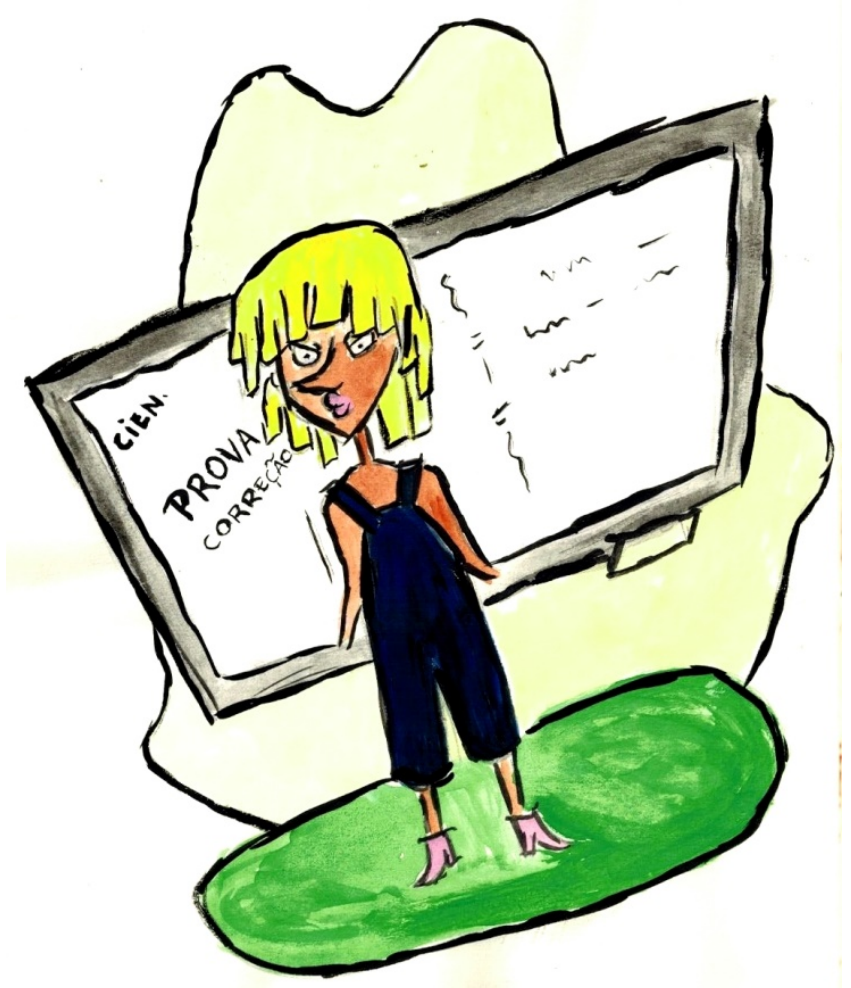

Imagem 2: Josélia de bom humor (aquarela). 
o insulto da feiura na escola: insurreições contra o capital

- Como assim? A prova não é hoje? - Aristeves parecia genuinamente surpreso.

- Cara, foi semana passada - Saci respondeu bem baixinho - Sexta-feira...

- VÉIO! FOI SEXTA? - Feioso não disfarçou e se virou bruscamente para o amigo sentado atrás de si - Caraaaaaaca! Mano! Eu falei que era pra tu me lembrar! Eu cheguei a estudar pra sua prova, Josélia, acredita? - disse se virando para professora - E esse safado aqui ficou de bitoca na quinta com os boyzinho e esqueceu do parça dele...

A professora bufou e respirou longamente.

- Aristeves, vamos fazer o seguinte? Eu termino de entregar as provas e, depois, se você ainda quiser, você faz a prova comigo... oralmente...

- Opa, adoro! - Feioso soltou na mesma hora, erguendo as sobrancelhas para ela.

- Se você acertar duas das três questões, eu lhe dou a média e você some da minha frente por, PELO MENOS, mais um mês.

- Caraca, Josélia, não sei se falo que te amo ou se me preocupo com você me querendo longe...

- No seu lugar, eu me preocuparia se eu lhe quisesse por perto - ela deu seu mais amarelo sorriso - Agora, continuando, teve gente que teve a ousadia de achar que minha matéria e a da professora de geografia são uma só e escreveu, de cima abaixo, "lençol" em todas as oportunidades de falar de um conjunto de células...

Se a turma, antes, tentou não reagir à estupidez dos colegas, decerto, o acordo não foi feito com Aristeves, que, imediatamente, danou a rir escandalosamente.

- ISSO É COISA DO SACI, É COISA DO SACI! - gritava ele, rindo e se contorcendo.

Depois disso, a turma não conseguiu mais manter o controle.

Josélia, claramente, preferiria não ter que lidar com as pestes dos alunos nesses casos. Olhou o relógio enquanto seus alunos riam e, dando-se por vencida, terminou de entregar as provas e passou matéria no quadro. Tentou pegar no pé 
do Aristeves com as três perguntas mais difíceis que conseguiu formular sobre a matéria que eles tinham estudado e, de praxe, o menino acertou as duas mais difíceis e errou a menos complicada claramente de propósito.

Quando a aula acabou, tudo o que Josélia fez foi pegar um calendário e marcar lá mais um dia. Mais 685 dias e ela se aposentaria.

\section{o apego à feiura}

Em 2007, Umberto Eco fez um compêndio elementar sobre a feiura, intitulado História da Feiura (ECO, 2007). Em seu trabalho, ele não apenas se preocupou em traçar como a feiura foi tratada, definida e criada ao longo da história da humanidade, como também apresentou recortes dela a partir de textos literários, filosóficos e obras artísticas. E, conforme o autor destacou em sua introdução, a feiura nem sempre - ou mesmo quase nunca - teve relação explícita com a aparência, com os traços do corpo. Na verdade, como fica bem evidente ao explorar as obras visuais estampadas nas páginas do seu trabalho, a feiura em muito se deveu a contextos políticos, às emoções, às amizades ou à economia. "Muitas vezes, as atribuições de beleza ou de feiura eram devidas não a critérios estéticos, mas a critérios políticos e sociais" (ECO, 2007, p. 12).

Isto é, nem sempre, ao longo da história, o feio foi o corpo grotesco, o deformado, o magro, o gordo, o anão, o gigante etc., ainda que a feiura estivesse no bobo da corte, na cigana, no andarilho, no pobre. É que, onde o feio habita, há sempre um mundo ideal, há sempre a perfeição a ser alcançada e, porque feios, representam simplesmente "a imperfeição do universo físico em relação ao mundo ideal" (ECO, 2007, p. 25).

Tradução, a feiura é verdadeiramente imanente e não deseja outra coisa.

Assim somos atravessados pela cena entre Josélia, Aristeves/Feioso e Saci. Josélia, professora-dominatrix, é quase a figura máxima da autoridade na escola e, ainda assim, quando cruza o caminho da feiura, é quase colocada no lugar da submissão, impõe seu desejo controlador e, antes de ser temida, é apreciada. A vida - na figura do Feioso - dribla o desejo controlador ao dar ao controle certos 
o insulto da feiura na escola: insurreições contra o capital

tons afetivos. A feiura, como a cena entre a regulação e a desobediência sugere, tudo tem a ver com as resistências.

Davis Alvim (2011), inspirado em leituras deleuzianas, defende em sua tese que a resistência não presta continência a nada. Bárbara, a resistência espraia-se pelo plano liso muito antes de qualquer forma de controle e, portanto, em nada deve à definição do dicionário, isto é, resistência reativa. Na mesma direção, Michael Hardt e Antônio Negri (2016, p. 99) lembram que, "por paradoxal que pareça, a resistência é anterior ao poder".

Esse caráter de resistência bebe diretamente de Gilles Deleuze em suas escritas com Félix Guattari. Podemos encontrar, por exemplo, no platô 10.000 a. C. - A geologia da moral (Quem a Terra pena que é?) toda uma discussão sobre o plano liso da Terra que foge sem parar, flui com intensidades ora demasiado fortes, ora ridiculamente lentas (DELEUZE; GUATTARI, 2011a). A resistência deleuzoguattariana não se inscreve sobre algo, é sobre ela que outras forças se inscrevem. São superfícies sem organelas, sem investimentos de poder - "Ela é a superfície sobre a qual se inscreve todo o processo de produção, sobre a qual são registrados os objetos, os meios e as forças de trabalho" (DELEUZE; GUATTARI, 2011b, p. 187).

Os corpos, quando capazes de transitar nessa lisura, carregam um entre para serem capazes de sentir os afetos da Terra, da vida fugidia. Janete Magalhães Carvalho (2019, p. 50) fala: "Queria tocar um lugar. Mas um lugar me toca".

É o liso fugidio que nos toca. E isso é a resistência deleuziana, a resistência que não se preocupa em produzir códigos. Ela é pré-código, pré-símbolo, précorpórea; é apenas desejo.

O poder se inscreve sobre a resistência.

No nosso caso, o poder é o controle sobre os corpos.

Em dada passagem do texto, Alvim lembra que o produto do poder se incita por relatividade e, portanto, é incapaz de existir por si só. Assim, decerto, é a beleza criada no campo dos signos capitalísticos. Mas a feiura foge sem parar.

E, conforme Paul Preciado (2018) sugeria, a feiura atrela-se a um nível de gostosura, a certo apego ao corpo. O feio não é quem não se sente bem com seu 
corpo, mas quem cria usos para ele inexplicáveis a quem apenas vive por seguir as regras estéticas do Capital.

Se se entende a beleza enquanto essa linha que se inscreve sobre a terra lisa, percebemos que, antes de qualquer controle estético, há infinitas possibilidades estéticas na qual a feiura pode ser largamente encontrada em meio a tantas outras. Se vemos na beleza os traços sedimentares de políticas duras - isto é, se entendemos que o belo surge a partir de definições controladas e regulamentadoras -, logo notamos o feio como possibilidade da materialidade dos corpos. Antes de qualquer tecido estriado se lançando sobre uma terra, havia tão somente feiuras para todos os lados. Feiuras e outras existências irrequietas.

Ante qualquer cara de asco ou desgosto, talvez fosse necessário experimentar a feiura para dar-se conta do longo gozo que esses corpos produzem, das relações possíveis para além da competição e da desavença.

\section{fábula2: sempre cabe mais um}

Apesar de toda a fama de brava, Josélia sempre foi bem vista na escola, mesmo pelos alunos. Talvez fosse só porque ela não negava carona a ninguém e, com isso, acabasse sempre levando pelo menos quatro para a cidade junto com ela todo dia. Ela nem perguntava mais. Quando saía da escola, lá estavam quatro ou cinco ou seis alunos parados perto do seu carro já esperando por ela. Às vezes, eles davam um doce a ela - ela nunca aceitava dinheiro - ou apenas contavam as últimas fofocas da escola.

A fama era de durona, mas Josélia passava os vinte minutos de viagem no carro se divertindo com os alunos que sabiam muito bem quais histórias ela gostava de ouvir, quais ela os olharia com a expressão de professora brava.

Às vezes, ela desconfiava que alguns deles iam com ela no carro só para ela não ficar tão sozinha. Em compensação, tinha dias que ela tinha certeza de que um ou outro aluno usava esse tempo para tentar descobrir o que iria cair na próxima prova dela ou se ela seria bondosa o suficiente na correção de algum trabalho.

Não é que ela se arrependesse desses dias - ela gostava de ser bajulada pelos alunos -, mas sempre ficava com uma sensação triste quando lembrava que, 
o insulto da feiura na escola: insurreições contra o capital

logo, não mais iria passar por isso. Não que ela quisesse continuar trabalhando depois da aposentadoria. Ela não seria uma dessas loucas que se aposentam e voltam a trabalhar, voltam a fazer processos seletivos e tudo o mais. Não, já tinha planos: ia se aposentar nas duas cadeiras e começar a fazer mochilão pela América do Sul com o namorado dela. Eles já vinham fazendo os planos do trajeto todo. Ele ia estar com 66 anos e ela com 50. Ao menos os dois teriam idade o suficiente para pedir água pelas casas sem causar muito rebuliço. A melhor parte de mochilar na terceira idade!

Certa vez, Josélia e os professores tinham ficado até de noite na escola para uma reunião chata de escola. Tinha começado como plano de ação e terminou com avaliação institucional, ou seja, uma chatice só. Já era tarde quando eles saíram quase nove da noite! - e, pasma, Josélia encontrou um aluno encostado em seu carro.

Ela estava acostumada, mas não àquela hora da noite.

- Josélia, minha linda! - disse o rapaz, dando um abraço efusivo na professora - Pode me dar uma carona?

Aristeves. E ele fedia a álcool.

Ela hesitou apenas por um segundo. Abriu a porta do carro para ele, colocou ele para dentro e prendeu o cinto de segurança dele. Nunca tinha acontecido antes, mas ela conhecia as famílias daquele bairro. Ele possivelmente apanharia feio se chegasse em casa bêbado. E nunca tinha visto o menino beber ou ouvido falar disso, então alguma coisa devia ter acontecido. Não que ela estivesse curiosa, mas certamente estava preocupada.

- Você só me mete em enrascada, Aristeves - ela disse enquanto dirigia.

Ele sorriu e mandou um beijinho para ela no ar.

Ela o levou para a casa dela e, com a ajuda do namorado, deram um banho nele e o colocaram para dormir no de hóspedes deles.

- Ele é o que te dá trabalho sempre? - o namorado perguntou.

- O próprio.

- Entendo porque você gosta tanto dele. Mesmo bêbado ele inspira alegria. Josélia não se deu por vencida. 
- Não se iluda, essa alegria toda que você está sentindo é o cheiro de álcool. Vai passar.

Ele riu.

No dia seguinte, quando Josélia e Aristeves chegaram à escola juntos, a escola inteira ficou de cochicho. Josélia já esperava isso, então, para ter certeza de que a coisa ia andar como devia, ela ficou para trás e esperou Feioso passar na sua frente.

- Vai lá, gostoso - disse ela e deu um tapa na bunda dele.

- Iiiiih, Feioso, domou ou foi domado?

Josélia sorriu. O segredo do garoto estava a salvo. Ele não iria apanhar quando chegasse em casa. Para ela, era o que importava no momento.

\section{insurreições, amizades, vagabundagens}

É evidente: a feiura não é apenas a figura do Feioso em seu corpoimplicante, mas também Josélia, Saci, Ismeli, Anael.... Josélia, que em sala de aula é a figura da autoridade, flerta livremente com a feiura sem temê-la. Antes de causar-lhe dor ou desespero, provoca um gosto inesperado pela vida. "Sinto-me aviltada perto de ti, que felicidade! Como é tedioso ser alteza! Decair é repousante. Estou tão saturada de respeito que preciso de desprezo [...] Amo-te não só porque és disforme, mas porque és abjeto" (ECO, 2007, p. 286).

Talvez por isso possamos aliar a feiura à insurreição. Ela, ao inspirar um apego sem igual à vida, provoca insurreições em nível micromolecular, entre os corpos que se relacionam com as feiuras.

E, sendo insurrecionais, as feiuras debocham do desejo pretensioso de paz.

Partimos aqui da premissa de que a paz não apenas é ilusória como sua existência mancharia os corpos com a não vida. "Abandonar a ideia de paz é a única paz verdadeira" (COMITÊ INVISÍVEL, 2016, p. 45). A paz, garantem, não é sinal de bondade, mas antes "ou uma profunda burrice ou uma completa má-fé", visto que a "recusa tática do confronto é ela mesma uma astúcia de guerra" (ibid., p. 168).

Paradoxalmente, essa afirmação é demasiadamente ética. 
o insulto da feiura na escola: insurreições contra o capital

Isto é, ao recusarmos a ideia de paz, passamos a lembrar que os corpos com os quais nos relacionamos possuem vida, possuem posicionamentos diante do mundo e, por isso mesmo, há sempre o risco de entrarmos em um confronto. Recusa-se a paz porque ela, simplesmente, porque para que essa exista, dever-seia existir uma única forma de vida, um único corpo, um único modo de enxergar o mundo.

A feiura, de imediato, recusa a promessa da paz mundial.

Diante da paz, nada mais fazemos que aquiescer. O corpo pacífico é o corpo de resposta impossível, de concordância eterna. A nosso ver, isso nada mais é que a produção do vazio de vida. Porque isso é o produto de uma paz pretendidamente verdadeira: a não vida ou, no mínimo, uma vida pacificada, uma vida controlada.

No fundo, a rejeição da guerra só exprime uma recusa infantil ou senil em admitir a existência da alteridade. A guerra não é a matança, mas sim a lógica que regula o contato de potências heterogêneas. Ela é travada por todos os lados, sob inúmeras formas, e na maioria das vezes por meios pacíficos. Se há uma multiplicidade de mundos [e de estéticas], se há uma irredutível pluralidade de formas de vida, então a guerra é a lei de coexistência nesta terra (COMITÊ INVISÍVEL, 2016, p. 167).

Faltaria à vida a coragem da discordância, de rir mais alto, de incomodar o outro. Ou melhor, não faltaria a coragem e sim a possibilidade qualquer de dissonância.

E caso ainda reste alguma dúvida, lembremos apenas ser em nome da paz que nos morros se ouvem disparos de fogos de artifício sem nenhuma luz brilhante no céu; é em nome da paz que a polícia brasileira assassinou 6.160 pessoas em 2018; é em nome da paz que “a política da morte não cansa de ser ativada. Portanto, é preciso assumir a ruptura com a sedutora e paralisante conciliação de classes, com o sistema de pactos e conciliações que anestesiou as forças de transformação" (CENTELHA, 2019, p. 43). Nos termos da Rolnik (2018, p. 71), deparamo-nos com esses autodeclarados pacificadores que não são senão "traficantes de receitas de uma paz redentora".

Para infortúnio dos pacifistas, vemos na feiura um quê de insurreição. $O$ corpo feio não quer paz. Na verdade, é contra ele mesmo que a paz é proclamada. 
Feioso bem o sabe. Por onde Feioso passa, a coordenadora fica já com as orelhas atentas, esperando sempre a perturbação de algo, o fim dos acordos táticos. Ao entrar na aula da Josélia - pelo menos dez decibéis mais alto que o esperado -, a paz momentânea foi ruída por um cumprimento acalorado. Josélia possivelmente criara esperanças enquanto via na sala a ausência de Feioso. E, de repente, irrompe Feioso em sala acabando com todos os falsos acordos silenciosos. Agora alunas e alunos não mais precisam disfarçar seus risos. Com Aristeves em sala, os conflitos são postos às claras.

Na insurreição não há esperanças.

Insurrectos, corpos feios se lançam infinitamente ao tempo, não temendo a ordem do agora. Feioso é carne do agora. Na aula de Josélia, já chega esperando por uma prova que já passou e, entretanto, não se deixa levar por isso. O tempo ainda urge, ainda flui e, ao invés de esperar a caridade, age, torra a paciência de Josélia até que esta, percebendo-se diante de um corpo-fluxo-do-tempo, não vê alternativa senão lhe oferecer o presente do tempo.

Em momento algum, a feiura cria esperanças sobre o mundo. Há muito ela aprendeu que o sorriso de uma criança esperançosa conquista leilões de doadores pelo simples fato de expressar a segurança do amanhã. A insurreição não dá o amanhã como dado e, por isso, não o espera. Antes, ela aceita ou recusa o embate, a discussão. Sendo redundante, o Comitê Invisível (2017, p. 19) faz o mais caro dos pleonasmos para nós: “É o presente e, portanto, o lugar da presença”.

Toda feiura, sendo insurrecta, faz-se presente por obrigação.

O nascimento de Feioso - nome próprio por direito muito antes de ser um apelido - marca justamente o nascimento da presença do corpo. Feioso nem sempre está na escola, mas, em cada momento ali, ele está de corpo inteiro, é um acaso da duração.

Esse tipo de corpo confabula com o presente. Não há modos de encontrá-lo sem antes produzi-lo. Aristeves, por vezes, pode ser encontrado matando aula, conversando na cozinha ou mesmo com Ismeli, que, apesar de não mostrar, tem um enorme apreço por ele. Aristeves está lá, na escola, mais vezes do que 
o insulto da feiura na escola: insurreições contra o capital

imaginamos. Mas ele passa como qualquer outro menino. Feioso, por sua vez, irrompe.

Não para menos, o século XX produziu um tipo de feiura tão pouco preocupada com padrões estéticos - "o feio de hoje é sinal de grandes transformações por vir" (ECO, 2007, p. 365). Apesar de ser criado partindo de regras culturais, a feiura surgida aí compra brigas, enuncia incompetências, desastres. Haveria, talvez, uma feiura política, seja por efeito de denúncia social, seja em razão de provocações estéticas pouco convencionais.

E nossa política não é, em absoluto, a política da reforma.

Safatle (2018, p. 16) pontua que “o desejo anti-institucional, quando realmente liberado, pode criar poderes que voltam às mãos do povo, democracias que abandonam a representação para transferir a deliberação e a gestão para a imanência do povo". O Comitê Invisível (2017, p. 94-95) diz, por sua vez, que, em uma lógica destituinte, se luta "por uma deserção das relações de merda consigo mesmo, com os outros e com o mundo". E, em meio a tudo isso - e com uma pegada mais negriana que o Comitê Invisível -, Alvim (2011, p. 97) vai destacar que a "criação tem como pré-condição uma forte recusa". Recusa-se o mundo, destroem-se os palácios, mas para fazer os escombros e as ruínas existirem por si mesmos, para criar, a partir dos sem-fundo (LAPOUJADE, 2016), uma praça aberta.

Aliada à resistência, a insurreição faz amizades.

A lógica capitalística de relacionamento é uma cena típica entre meninos de escola na qual eles se colocam em uma competição eterna de cuspes: um cospe e todos os outros se esforçam para fazer o cuspe ir mais longe. Quando um vence, os outros comemoram com ele por apenas três segundos. Não mais que isso. Mal se goza a vitória, a competição já recomeçou. Seja lá qual for o utensílio ejaculador.

Intensifiquemos a cena: um ganha; o outro que chegou bem perto se irrita; o terceiro chora por não conseguir juntar saliva; o último se diz indiferente a tudo isso, ainda que tente cuspir toda vez que o jogo recomeça. Se conseguirmos olhar a cena completa, ainda veremos que esses quatro meninos estão, de modo incompreensível, tentando conquistar a mocinha simpática se remoendo de nojo 
ou rolando de rir da estupidez alheia. Todos sabemos que ela é esperta e já beijou todos eles - e mais uma penca - prometendo-lhes, quem sabe, o direito de outro beijo. Essa é a cena do controle capitalístico ilustrado na escola. Coisa boba. Verifica-se de tudo um pouco: a moça bela, as subjetividades individualistas, as tecnologias pré-verbais fazendo o trabalho delas, a lógica de gozo curto versus gozo demorado, a traição, a heterossexualidade compulsória, o consumo subjetivo... Enfim, um pouco de tudo encontramos numa cena tão breve. Todavia, se se insere nessa cena um corpo feio - Feioso, quiçá -, ela muda radicalmente. Feioso, ouso dizer, sairia direto para beijar a mocinha. Se realmente conseguissem convencê-lo a jogar sob aquelas estúpidas regras, ele provavelmente se juntaria com um e outro até dar certo. Ou simplesmente aceitaria que nada disso dá certo e riria de si loucamente.

Sob a presença jocosa e insurrecta do corpo feio, a mocinha não teme revelar-se punk ou puta e dar a melhor das cusparadas. Quando a competição pelo corpo feminino não é mais obrigatória, talvez dois dos meninos comecem uma pegação própria, às claras. Talvez até dois deles continuem a cuspir, ainda que só por brincar, enquanto a boca esganiçada do Feioso ri de tudo.

As possibilidades são infinitas, mas, certamente, ele não precisaria encherse de um ego enfadonho para galantear para os outros, enquanto fingia galantear para a menina. No lugar do galanteio, a feiura produz relações de proximidade. Bem verdade que ainda é possível manter certa competição entre feios, mas, por vezes, o estereótipo da autossuficiência é rompido.
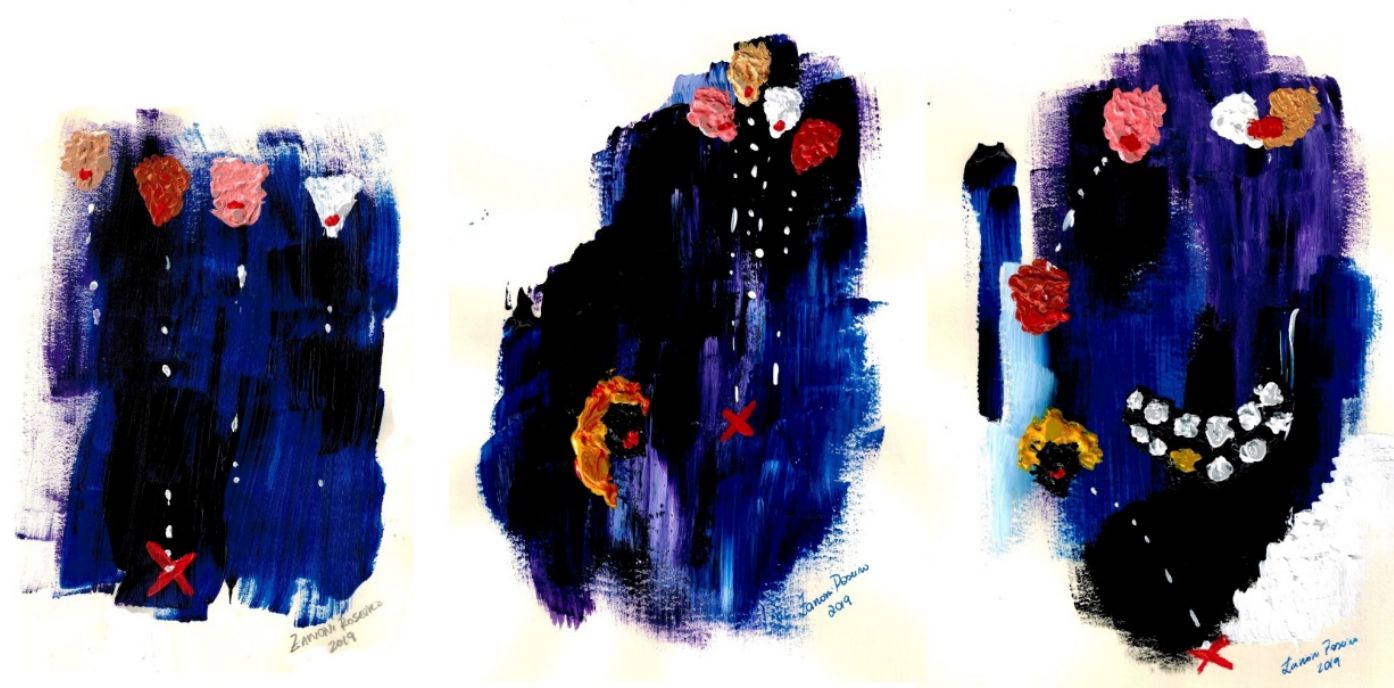
o insulto da feiura na escola: insurreições contra o capital

Imagem 3: Três ensaios sobre uma cusparada (acrílica).

O feio é tão danoso para o individualismo que mesmo um toque pode levar um corpo ao desespero e criar as mais desordeiras cenas. Josélia, quando se dá ao contato com a feiura, larga toda a ideia de controle e de pacificidade. No limite, faz-se mais jovem, lembra que os corpos são táteis. N'algumas vezes, lembramos sermos dependentes uns dos outros. Feioso deixa bem claro que contava com o Saci para se lembrar da prova, assim como conta com Josélia para levá-lo para um lugar qualquer, para fugir de certos riscos.

$\mathrm{Na}$ biologia, esse afeto que se manifesta pelo diferente a ponto de criar relação de cuidado e implicância foi chamado por Nikolaas Tinbergen de tendência supernormal (MASSUMI, 2017). Na biologia, esse conceito é explicado com o exemplo do filhote de cuco colocado em um ninho, mas, aqui, claramente podemos dizer do filhote de cuco - Feioso - que coloca a si mesmo em contato com outros filhotes de pássaro para se ensinarem mutuamente. Talvez, como Massumi (ibid., p. 38) destaca, seja preciso reconhecer "que os movimentos instintivos são animados por uma tendência a superar as formas dadas, movidos por um ímpeto à criatividade".

Ou seja, talvez precisemos reconhecer que a feiura atrai outras feiuras, ou, de modo ainda mais peculiar, produz feiura onde antes aparentava haver só belezas. Diz-se que uma moça bonita anda com uma amiga feia para se fazer mais bonita; ao contrário, a bela moça de King Kong anda com a besta para não precisar estar sempre certa, sempre sob controle (DESPENTES, 2016). E, no lugar de competirem fatalmente entre si, passam a vivenciar, juntos, experiências infinitas de vida passível de ser vivida na mutualidade.

No limite, onde a amizade se cria, surge a vagabundagem como condição.

Nos contextos capitalísticos em que tudo deve ser funcional, pausas inoperantes são vistas com péssimos olhos (ROSEIRO; SILVA, 2018) e, por isso mesmo, são da ordem da feiura.

Vivendo uma era em que o controle sobre o corpo é acessível a todos e largamente difundido como desejável, os corpos vagabundos - inoperantes, desocupados, despreocupados - são apontados a torto e a direito como 
preguiçosos, como improdutivos (SANT'ANNA, 2014), como corpos inócuos e apáticos.

Bastar-lhes-ia apenas um toque de dedicação e boa vontade para serem, ao menos, reconhecidos.

A feiura vagabunda é do tipo de feiura que se ocupa em não dar continuidade às operações demasiado lucrativas à maquinaria Capital. Sabemos, logicamente, que, quando até o ar foi capitalizado, é impossível acreditar haver qualquer coisa improdutiva, mas gostamos da ilusão desse termo, gostamos da possibilidade de, pelo menos, fazer uma engrenagem do maquinário girar mais devagar ou criar um curto-circuito rápido.

Isso é algo que qualquer feio - estético ou político - sabe muito bem fazer: contrariar as rocas e as engrenagens. E, quando possível, talhar nelas uma armadilha ou outra para trair, aos poucos, a malandragem capitalística. Afinal, como João Antônio (2009, p. 153) lembra, é imperdoável o malandro orgulhoso, o malandro que se desfaz das amizades. "Malandro ganhar vinte contos, não dar mimo a ninguém, não distribuir as estias! Que malandro era esse? Aquilo era um safado precisando de lição!".

Em 1947, Fernand Deligny (2018) publica um livro maravilhoso intitulado Os vagabundos eficazes em que faz um relato sobre seu período como diretor de um instituto de educação-correção de jovens. E, para que não restem dúvidas, Deligny acusa largamente seus alunos de serem vagabundos que ora fogem do trabalho, por isso aparecem à sua porta, ora fazem fanfarra pelas ruas, por isso são impedidos de fazer figuras públicas.

Em resposta, os alunos apontam-no como o maior dos crápulas.

Seja como for, Deligny mostra-nos, em seu trabalho, justamente o quanto a vagabundagem é indecorosa, e, por isso mesmo, feia até seu último fio de cabelo. O corpo-vagabundo é da ordem da delinquência, da insensatez, mantendo, em suas ações, o máximo possível do deboche.

Para se proteger da polícia e da prisão por reincidência, os meninos do Centro que iam à cidade levavam no bolso uma permissão devidamente datada e carimbada. Com essa permissão, exibida em qualquer ocasião, tentavam conseguir meia-entrada no cinema, dar voltas gratuitas nos carrosséis das feiras, não pagar o 
o insulto da feiura na escola: insurreições contra o capital

bonde, evitar fila nos guichês da estação de trem. E eles eram tão persuasivos, em sua alegria elementar de estar "em ordem" na participação de um grupo, que a extravagância do oportunismo encontrava pouca resistência (DELIGNY, 2018, p. 67).

A vagabundagem diz, portanto, de um corpo que se sabe em jogo e, por isso mesmo, faz usos das forças para questionar a ordem, para se passar por desinteressado, corpo distante. A vagabundagem faz juras de amor às inquietações, às perguntas que não permitem respostas pré-fabricadas.

Em um navio pirata no oriente, talvez pudéssemos observar a vagabundagem ganhar sua forma mais singela em um sorriso totalmente errado: um sorriso que se estica demais, faz barulho demais e, ainda por cima, faz o barulho errado. Shi shi shi shi shi, ri o pirata a bordo ${ }^{5}$. Ainda assim, é uma risada marota que conquista amizades e faz guerra contra todos os imperadores do mar, contra o céu e a polícia; uma risada que, de quando em vez, coloca outros em perigo apenas para serem obrigados, juntos, a pensar em alternativas.

Aliada à insurreição, resistência e amizade, a vagabundagem junta quatro vozes para dizer: Juro solenemente não fazer nada de bom (ROWLING, 2000).

\section{lutas contra o capital}

Ora, é exatamente esse movimento indecoroso e debochado, sorridente e companheiro que o corpo-feio se vale para enfrentar as situações em que as regras lhe são contraproducentes. A feiura vagabundeia e cria para si tempo de encontros, estratégias insurrecionais, mapas inventivos. Em uma lentidão criadora, a feiura não bate continência, antes dá no pé diante de qualquer organela libidinal.

Porque sempre acompanhada, a sem-vergonhice do corpo-feio sai em debandada.

Nas escolas, fazemos nossas lutas declaradas contra o empobrecimento da vida, por isso guerreamos o Capital. Aristeves talvez não faça dessa guerra algo tão declarado quanto nós, mas, enquanto criávamos o personagem e suas

\footnotetext{
5 O pirata em questão é Monkey D. Luffy, personagem criado por Oda Eiichiro em julho de 1997. Por não trabalhar com um volume específico, não foi feita a referência.
} 
histórias, era isso que efetivamente fazíamos: fortalecíamos as relações entre nós e diminuíamos os desafetos para com a vida.

Fizemos da arte de criar histórias - a fabulação - um modo de declarar nosso apego à vida (LAPOUJADE, 2014) e um modo de nos aliarmos às potências da feiura. A escola, se nos atentarmos bem, é invadida por feiuras inimagináveis.

No lugar de embelezarmos as vidas desses espaços, muito mais propícia seriam as práticas de enfeamento coletivo.

Em miúdos: a feiura é tão criativa quanto mais os agenciamentos exigem dela um controle. Se lhe exigem beleza, ela responde na vagabundagem; se lhe querem controlada, ela se insurreciona; se lhe rogam para tomarem conta de si, ela chama pelas amizades; se se deseja seu fim, ela resiste.

Eis, simplesmente, o insulto da feiura.

\section{post-scriptum da feiura}

PS1. Evite deixar-se usar de sua feiura para virar artífice comparatório da beleza d'outro. "Um certo Durandeau percebe que, quando se vê passeando juntas duas mulheres das quais uma é visivelmente feia, todos, por contraste, acham a outra mais bonita. Decide, então, fazer um comércio de feiura" (ECO, 2007, p. 293).

PS2. Toda feiura pode, sem exceção, ascender ao patamar de vanguarda. Proíba-se isso.

PS3. Não seja o bom feio, o feio adereço. Faça da feiura uma vida a se espraiar.

PS4. Na feiura, nunca perca a força da violência contra o presente.

\section{referências}

ALVIM, Davis Moreira. Foucault e Deleuze: deserções, micropolíticas, resistências. (Tese de Doutorado). São Paulo; PUC-SP, 2011.

ANTÔNIO, João. Malagueta, Perus e Bacanaço. 4. ed. São Paulo: Cosac Naify, 2009.

CARVALHO, Janete Magalhães. Macro/micropolítica, cotidiano escola e constituição de um corpo coletivo em devir. Educação Temática Digital, Campinas/SP, v. 21, n. 1, jan./mar. p. 47-62, 2019.

COMITÊ INVISÍVEL. Aos nossos amigos: crise e insurreição. Trad. Edições Baratas. São Paulo: n-1 edições, 2016.

COMITÊ INVISÍVEL. Motim e destituição agora. Trad. Vinicius Honesko. São Paulo: n-1 edições, 2017. 
o insulto da feiura na escola: insurreições contra o capital

DELEUZE, Gilles. Conversações. Trad. Peter Pál Pelbart. 3. ed. São Paulo: Ed. 34, 2013.

DELEUZE, Gilles; GUATTARI, Félix. Mil platôs: capitalismo e esquizofrenia 2, vol. 1.

Trad. Ana Lúcia de Oliveira, Aurélio Guerra Neto e Celia Pinto Costa. 2. ed. São Paulo: Ed. 34, 2011a.

DELEUZE, Gilles; GUATTARI, Félix. Kafka: por uma literatura menor. Trad. Cíntia Vieira da Silva. Belo Horizonte: Autêntica Editora, 2014.

DELEUZE, Gilles; GUATTARI, Félix. O anti-Édipo: capitalismo e esquizofrenia 1. Trad. Luiz B. L. Orlandi. 2. ed. São Paulo: Ed. 34, 2011 b.

[DELEUZE, Gilles; GUATTARI, Félix. O que é a filosofia? Tradução de Bento Prado Jr. e Alberto Alonso Muñoz. Rio de Janeiro: Editora 34, 1992.

DELIGNY, Fernand. Os vagabundos eficazes: operários, artistas, revolucionários: educadores. Trad. Marlon Miguel. São Paulo: n-1 edições, 2018.

ECO, Umberto. História da feiura. Trad. Eliana Aguiar. Rio de Janeiro: Record, 2007.

LAPOUJADE, David. Deleuze, os movimentos aberrantes. Trad. Laymert Garcia dos Santos. São Paulo: n-1 edições, 2015.

LAZZARATO, Maurizio. Signos, máquinas, subjetividades. Trad. Paulo Domenech Onetto. São Paulo: n-1 edição; SESC, 2014.

LIPOVETSKY, Gilles; SERROY, Jean. A estetização do mundo: viver na era do capitalismo artista. Trad. Eduardo Brandão. 1. reimp. São Paulo: Companhia das Letras, 2015.

MASSUMI, Brian. O que os animais nos ensinam sobre política. Trad. Francisco Trento e Fernanda Mello. São Paulo: n-1 edições, 2017.

MILITO, Caio Anawate Kuri. Culto ao corpo na publicidade: tecnologias para a construção do eu. (Dissertação de mestrado). São Paulo: UESP, 2012.

PRECIADO, Paul B. Testo junkie: sexo, drogas e biopolítica na era farmacopornográfica. Trad. Maria Paula Gurgel Ribeiro e Verônica Daminelli Fernandes. São Paulo: n-1 edições, 2018.

ROLNIK, Suely. Esferas da insurreição: notas para uma vida não cafetinada. São Paulo: n-1 edições, 2018.

ROSEIRO, Steferson Zanoni; SILVA, Sandra Kretli da. Currículos disfuncionais: inventar as lutas contra o capitalismo. Educação \& Realidade, Porto Alegre, v. 43, n. 3, p. 1115-1130, jul./set., 2018.

ROWLING, Joanne Ketlin. Harry Potter e o prisioneiro de Azkaban. Trad. Lia Wyler. Rio de Janeiro: Rocco, 2000.

SAFATLE, Vladimir. Um dia, esta luta iria ocorrer. Série Pandemia. São Paulo: n-1, 2018.

SANT'ANNA, Denise Bernuzzi de. História da beleza no Brasil. São Paulo: Contexto, 2014.

recebido em: 16.11.2019

aprovado em: 22.02.2020 